\title{
BIOACCUMULATION OF HEAVY METALS AND THEIR EFFECT ON VITAL ORGANS OF LABEO ROHITA IN PONDS AND NATURAL WATER BODIES
}

\author{
G. Islam ${ }^{1}$, F. Abbas 2 , M. Hafeez-ur-Rehman ${ }^{2}$ and M. Ashraf ${ }^{2}$ \\ ${ }^{1}$ Department of Environmental Sciences, University of Veterinary and Animal Sciences, Lahore-Pakistan \\ ${ }^{2}$ Department of Fisheries and Aquaculture, University of Veterinary and Animal Sciences, Lahore-Pakistan \\ Corresponding Author,s email: mhafeezurehman@uvas.edu.pk
}

\begin{abstract}
Labeo rohita was sampled to determine the contamination levels of chromium, lead, nickel, copper and manganese from wild (Trimmu and Balloki Headworks) and controlled fish ponds at Ravi Campus (UVAS) from September to December, 2013. Sampled fish were blotted dry, weighed and liver and intestine were removed to study histology and metals concentration. Chromium seems ubiquitous and was detected in all the water samples as well as liver and intestinal tissues of experimental fish. Its level was lowest in water samples and fish organs in samples collected from UVAS fish ponds while the highest in samples collected from Balloki Headworks, the main recipients of waste from Lahore city. Fish liver depicted Chromium $(\mathrm{Cr})$ only but the intestine revealed the presence of Nickel $(\mathrm{Ni})$, Lead $(\mathrm{Pb})$, Manganese (Mn) and copper $(\mathrm{Cu})$ too. Cadmium was below the detectable limit in all water and tissues (liver, intestine) of sampled fish. Heavy metals load and their range induced pathological alterations, infiltration and necrosis in liver and intestinal tissues. Canonical discriminate analysis of $\mathrm{Cr}, \mathrm{Cu}, \mathrm{Mn}, \mathrm{Ni}, \mathrm{Pb}$ and $\mathrm{Cd}$ and the extent of histopathological changes differed significantly among localities establishing an appropriate link with living media and their vertical flow in fish.
\end{abstract}

Key words: Labeo rohita, heavy metals toxicity, water sources, vital organs, histo-pathological changes.

https://doi.org/10.36899/JAPS.2021.1.0213

Published online August 26, 2020

\section{INTRODUCTION}

Heavy metals are naturally found in aquatic environments as positive ions and now they constitute a considerable part of water pollution due to anthropogenic activities like industrialization, urbanization, as well as commercial activities. Although, these are basically required for the normal functioning of aquatic creatures but the excessive amounts may accumulate in the aquatic animals like fish and gradually increase to levels causing toxic effect (Shah et al. 2012 \& 2013 and Izuchukwu et al. 2017). Heavy metals are among the most serious environmental pollutants due to their high toxicity, abundance and ease of accumulation due to their nonbiodegradable and non-thermo degradable nature and are extremely persistent in the environment (Guevara-Riba et al. 2004).

Heavy metals for example $\mathrm{As}, \mathrm{Hg}, \mathrm{Cd}$, and $\mathrm{Pb}$ are severe toxicant and have the ability to alter the freshwater quality and aquatic life, especially fish which sometimes can metabolize metals to even more harmful derivative compound (Shah et al. 2012 and Khan et al. 2012). Being the top consumers, fishes can have heavy metals in four routes via food consumption, water uptake (gills), consumption of nonedible particles and through skin absorption. The absorbed heavy metals accumulate in the different body organs especially in the liver, kidney and gills prior to being eliminated or stored (Azaman et al. 2015). Accumulation of heavy metals may reduce fish appetite and metabolic activities that leads to hamper growth and development (Javid and Saeed, 2010) and can be serious hazard when transferred to humans by fish consumption (Rahman et al. 2014). Thus, the fishes are suggested as environmental biomarkers and are considered as an early warning of environmental degradation (Verlecar et al. 2006). The gills (Alazemi et al. 1996), liver (Braunbeck, 1998) and kidney (Bernet et al. 1999) are the main organs for pollution target as these are the main sites for metabolic activity and hence can be used as bio indicator of metals bioaccumulation (AlGhanim et al. 2015).

Pakistan has been blessed with number of water resources with World's largest water distribution system but the anthropogenic activities destroy the water quality to such an extent that it became unfit for human and aquatic life (Muhammad et al. 2010 \& 2011; Khan et al. 2013). Industrialization and urbanization play a major roll in dumping of heavy metals in the environment up to the alarming level (Hussain et al. 2014) especially in the Indus River and its tributaries. Fatoki and Mathabatha (2001), Qadir et al. (2009), Qadir and Malik (2011), Javed and Usmani (2013), Cardwell et al. (2013), Khan et al. (2018) and many other researchers have worked on heavy metal contamination but the information are limited. The objective of this study was to investigate the concentration of heavy metals in different organ of Labeo 
rohita selected from Balloki Headworks and Trimmu Headworks and was compared with fish cultured in the pond system at Fish Farm complex at Ravi campus, Pattoki.

\section{MATERIALS AND METHODS}

Location: Labeo rohita was collected from Trimmu Headworks located at the junction of River Chenab and Jhelum (District Jhang), Balloki Headworks at River Ravi (District Kasur) and from UVAS-Fish ponds, C-block Ravi Campus Pattoki, district Kasur in the month of September to December 2013. Fish were harvested, weighted and transported in the ice boxes to the histology lab of Anatomy and Histology department, UVAS, city campus, Lahore.

Histopathological studies of liver and intestine: Samples collected on monthly basis from the selected stations were subjected to histological studies according to Tao et al. (1999). Fish were dissected for intestine and liver, sliced and fixed in fixative solution containing ethanol, formaldehyde and glacial acetic acid (1:3:7). Tissues were dehydrated in ethanol and embedded in Paraffin wax. Histological sections of $2 \mu \mathrm{m}$ were then cut at a microtome and stained with hematoxylin-eosin. Light microscopy performed and stained section was photographed under photoscope.

Determination of heavy metals in fish: Metal analysis was done in the chemistry lab of Government College, University, Lahore. Samples of liver and intestine were subjected to the wet digestion in the anatomy lab for the metal analysis viz. chromium, copper, cadmium, lead, nickel and manganese following S.M.E.W.W. (1989). Tissues $(50 \mathrm{~g}$ each) were washed with deionized water, dried on blotting paper and digested in $5 \mathrm{ml}$ solution of perchloric and nitric acid at 200 to $250^{\circ} \mathrm{C}$ to obtain a transparent solution. $100 \mathrm{ml}$ double distilled water was added and heavy metals were analyzed through atomic absorption spectrophotometer.

Water Quality Analysis: Water samples (1L) from all studied sites were collected in water sampler bottles. The samples were collected below the surface about 2-3 feet away from the banks in such a way that no bubbles were allowed. Temperature, dissolved Oxygen, total dissolved solids (TDS), conductivity and $\mathrm{pH}$ were determined on site with the help of YSI Digital meters to establish correlation between type of water quality and response of fish. Further, samples were brought to the chemistry lab of Government College, University, Lahore for metal analysis (S.M.E.W.W, 1989). Water samples were filtered and preserved in $5 \mathrm{ml}$ of $55 \% \mathrm{HNO} / \mathrm{L}$ of water to prevent metal adsorption on the inner surface of the container and stored at $4 \circ \mathrm{C}$ before metal analyses
Statistical Analysis: Data collected were subjected to ANOVA for identification of statistical significance (Steel et al., 1996). Variable means among three different sites were compared using Duncan's Multiple Range Test to ascertain their level of superiority or inferiority. Probability level was set at $\mathrm{P}<0.05$.

\section{RESULTS AND DISCUSSION}

Statistical analysis of metal contamination indicate that water and fish organs contain less accumulation of heavy metals or even below detectable limits (BDL) in control culture system at Ravi campus, Pattoki except one water sample in which $\mathrm{Cr}, \mathrm{Pb}$ and $\mathrm{Cu}$ were detected. $\mathrm{Pb}$ and $\mathrm{Cr}$ were present in the intestine and $\mathrm{Pb}$ and $\mathrm{Cu}$ were present in the liver of pond fish. $\mathrm{Cr}$ was the only metal present in all the samples from the pond whereas, $\mathrm{Ni}, \mathrm{Mn}$ and $\mathrm{Cd}$ were below the detectable limits in water, intestine and liver of fish.

Statistical analysis of water samples from Trimmu Headworks indicates significantly higher concentrations of $\mathrm{Cr}$ whereas $\mathrm{Pb}$ concentration was highest at Balloki Head works. Other heavy metals were below detectable limits in both headworks. Intestine of fish samples from the Balloki head works showed higher concentrations for $\mathrm{Cr}, \mathrm{Pb}, \mathrm{Cu}, \mathrm{Ni}$, and $\mathrm{Mn}$ except $\mathrm{Cd}$ that was BDL. The intestine of Trimmu headworks fish showed higher concentrations of metals then the pond fish. The liver analysis indicates only $\mathrm{Cr}$ with higher concentration in Balloki Headwork followed by Trimmu headworks and Ravi campus pond complex, respectively. All the other metals were BDL in the liver. Thus the statistical analysis indicate that Balloki headworks had highest metal contamination as compared to the Trimmu headworks and ponds culture system. Lowest accumulation level in the pond system at Ravi campus, indicated that fish grown in the controlled system are more suitable for consumption. The values for the metals concentrations were quite higher from the maximum allowable concentration in the trimmu and Balloki headworks. The maximum allowable concentrations $((\mu \mathrm{g} / \mathrm{ml})$ for the metals are given in table 1 according to EPA (Mills, 1995).

The values for the $\mathrm{Pd}, \mathrm{Cr}$ were lower as compared to the values evaluated by the Chatha et al. (2016) who reported higher values for these metals and indicate the increasing concentration level of metals in the farmed fishes in Head Qadirabad area along the Chenab River and declare them not safe for human consumption due to the presence of $\mathrm{Pb}$, beyond acceptable limits. Similarly the values of $\mathrm{Pd}$ in the trimmu and Balloki headworks were higher than that of allowable ranges thus, the fish in that water bodies were not fit for human consumption. Presences of $\mathrm{Pb}$ beyond acceptable limits may cause headaches, inflammation, and abdominal pains. Children can experience loss of 
concentration and behavioral disturbances and in case of long exposures intellectual ability may decline (Jabeen and Javed, 2013). The consistent consumption of contaminated fish can also cause renal impairment (WHO, 2008).

Similar findings were reported by the Qadir et al. (2009) and Qadir and Malik (2011) from the Nullah Aik and Nullah Palkhu area supplied by untreated metal contaminants from tanneries and other industrial and city wastes from Sialkot and Wazirabad area. Similarly, Rauf et al. (2009) reported $\mathrm{Cd}$ and $\mathrm{Cr}$ in Labeo rohita and Cirrhinus mrigala with higher concentrations. Shivakumar et al. (2014) from india and Ahmad et al. (2015) from Karachi fish harbor reported higher metal concentrations due to the anthropogenic activities and industrial waste dumping into the natural water bodies. Our findings were also in accordance to the findings of Javed and Usmani (2013), Izuchukwu et al. (2017) and Khan et al. (2018) who reported that heavy metals bioaccumulate in the fish bodies that may be used as bioindicator of environmental pollution.

The maximum dissolved oxygen level was observed in Ravi campus fish ponds while the minimum level was in Balloki Headworks experimental site. The water temperatures in all three sites were in the range of $23.46 \pm 1.309$ to $26.0 \pm 0.816{ }^{\circ} \mathrm{C}$. Total dissolved solids were highest in Pattoki campus fish ponds followed by Trim Headworks and Balloki Headworks. Maximum electrical conductivity was in campus ponds while the minimum in Balloki Headworks. $\mathrm{pH}$ value was highest in campus ponds while minimum was recorded in Trimu Headworks (Table 2). Water quality parametrs like temperature and $\mathrm{pH}$ were within the acceptable ranges for fish culture in all three experimental sites however, values for DO and EC were lower in the trimmu and Balloki headworks that may retatrd the growth of fish and other aquatic animals. The value for TDS were within acceptable range in the Balloki and Trimmu headworks but was significantly higher in the pond culture system at Ravi campus Pattoki.

Histological studies of intestine: In Pakistan there are few studies on the effect of metals pollution on the aquatic organism and ecosystem (Waseem et al. 2014). Metal concentration in the fish intestine were studied by the Rajeshkumar and Li (2018) indicating higher values for the $\mathrm{Pb}$ followed by the chromium and copper however the data on the histopathology studies are scare especially on the intestine and related glands. In present study, pathological changes of fish intestine indicate the gut mucosa had lifted off (Fig. 3) and narcotized (Fig. 1-9). Individual epithelial cells appeared rounded up with dense chromatin and most of them were with eosinophilic cytoplasm. In some cases strips of epithelial cells appeared sloughed into the lumen (Fig. 3) giving appearance of copious catarrhal exudates (Fig. 9). There is an acute inflammatory response; particularly it was in the posterior part of the intestinal mucosa, which sloughs into the lumen. Apart from the degranulation of eosinophilic granular cells, there was also hyperaemia, infiltration of macrophages with massive necrosis of gut (Fig. 6). Khan et al. (2018) reported histopathological alterations in digestive gland i.e atrophy, hydropic vacuolation, necrosis, and lipofuscin which was in accordance of our results. Damage to intestinal tissue, particularly to enterocytes and villi structures, was detected histologically in tilapia by Younis et al. (2013). They reported degenerated nuclei and apoptosis in the crypts of Lieberkuhn and abnormally dilated lamina propria with inflammatory leukocytes at $10 \%$ of LC50 concentration of metals. Disturbed longitudinal muscularis and proliferation of mucous-secreting goblet cells indicated the defense mechanism against the pathological changes induced by $\mathrm{CdCl}_{2}$ contamination.

Histological studies of Liver: The parenchymatous tissue had many important physiological functions like the intermediate metabolism of protein, carbohydrate and lipid, the synthesis of plasma protein such as albumen, ovalbumen (reproductive protein) and also the formation and secretion of bile. It also cause the detoxification of endogenous waste products as well as externally derived toxins, drugs, heavy metals and pesticides. Anatomically it differs from that of higher animals in lacking fixed Kupffer cells lining the sinusoids, which, in mammals, are among the most significant components of the reticuloendothelial system (Hinton and Lauren, 1990, Latif et al. 2012).

Liver cell necrosis is a common finding in both primary liver disease and in reactive hepatitis in response to systemic infection. Small clusters of necrotic hepatocytes (focal necrosis) may be isolated within normal hepatic tissue. Focal necrosis and the various prior changes may be associated with a variety of toxic conditions, including virus infections, fungal infection and other toxic bacteremias, pesticide poisoning and heavy metal toxicity.

There were focal lesions which indicated confluent necrosis because it involved a significant area of liver (Fig. B). There were some areas which do not have inflammatory infiltrate but lot of dead cells or apparently dying were observed which are indicative of infarctive necrosis (Fig. C). Malignant hepatoma appeared in some cases, it was darkly stained and apparently appeared normal (Fig. A)

Fatty infiltration of liver cells is common in farmed as well as in wild fishes. It can be due to feeding on rancid fats, vitamin deficient diets or in toxic conditions. Presence of heavy metals have damaged cell membranes causing widespread necrosis and ceroid build-up in remaining hepatocytes with severe congestion and generalized intracellular oedema which is generally 
observed in fish exposed to algal toxin but heavy metal toxicity gave the same results (Fig. A-F). Hepatocytes swelled and contained large accumulation of ceroid within cytoplasm giving it granular appearance (Fig. E). Ceroid has aggregated to form intracellular nodules. Studies on Clarias gariepinus treated with sewage/domestic wastewater containing $\mathrm{Cu}, \mathrm{Fe}, \mathrm{Pb}, \mathrm{Cd}$, $\mathrm{Mn}$ and $\mathrm{Zn}$ (Authman et al. 2013) was also in accordance with present study.

There is a diffused increase in the fibrous tissue of the liver, usually associated with chronic damage and destruction of hepatocytes. This damage can result from a standing biliary obstruction, heavy metal or pesticide poisoning. Cirrhotic livers are occasionally seen in wild fish with little evidence for the cause. Cells of the nodule have become enlarged and bizarre in shape, enlarging and showing a high level of mitosis (Fig. D). Similar findings have been reported in liver of different fishes for example exposure of Oreochromis mossambicus (Van Dyk et al. 2007), Clarias gariepinus (Gabriel, 2007 a \& b), Channa punctatus (Mishra and Mohanty 2008 a \& b) and Channa striatus and Heteropneustes fossilis (Fatima and Usmani, 2013) to cadmimum and zinc compounds. Parvathi et al. (2011) exposed Cyprinus carpio to lethal concentrations of $\mathrm{Cr}$ whereas Tilapia zilli was exposed to Al by Hadi and Alwan (2012) reported degeneration of liver tissues and necrosis due to infiltration of leukocytes.

Table 1. Level of heavy metals present in water and tissues of liver and intestine of fish sampled from experimental sites

\begin{tabular}{|c|c|c|c|c|c|c|c|}
\hline \multicolumn{2}{|l|}{ Source } & $\begin{array}{l}\text { Chromium } \\
\text { (Cr) }\end{array}$ & $\begin{array}{c}\text { Nickel } \\
\text { (Ni) }\end{array}$ & $\begin{array}{l}\text { Lead } \\
(\mathbf{P b})\end{array}$ & $\begin{array}{c}\text { Manganese } \\
\text { (Mn) }\end{array}$ & $\begin{array}{l}\text { Copper } \\
\text { (Cu) }\end{array}$ & $\begin{array}{l}\text { Cadmium } \\
\text { (Cd) }\end{array}$ \\
\hline \multicolumn{2}{|c|}{$\begin{array}{c}\text { EPA (1995) Max. } \\
\text { allowable concentration } \\
(\mu \mathrm{g} / \mathrm{ml})\end{array}$} & 0.1 & 0.2 & 0.5 & 0.05 & 0.6 & 0.04 \\
\hline \multirow[t]{2}{*}{$\begin{array}{l}\text { Ravi } \\
\text { Campus }\end{array}$} & $\begin{array}{l}\text { Water } \\
\text { Sample }\end{array}$ & $0.288^{\mathrm{ac}}$ & BDL & $0.047^{b}$ & BDL & 0.0046 & $\mathrm{BDL}$ \\
\hline & $\begin{array}{l}\text { Intestine } \\
\text { Liver }\end{array}$ & $\begin{array}{l}0.107 \pm 0.03^{\mathrm{bc}} \\
0.125 \pm 0.16^{\mathrm{bc}}\end{array}$ & $\begin{array}{l}\text { BDL } \\
\text { BDL }\end{array}$ & $\begin{array}{c}0.090 \pm 0.02^{\mathrm{a}} \\
\mathrm{BDL}\end{array}$ & $\begin{array}{l}\text { BDL } \\
\text { BDL }\end{array}$ & $\begin{array}{c}\text { BDL } \\
0.0051 \pm 0.01^{b}\end{array}$ & $\begin{array}{l}\text { BDL } \\
\text { BDL }\end{array}$ \\
\hline \multirow[t]{2}{*}{$\begin{array}{l}\text { Balloki } \\
\text { Headworks }\end{array}$} & $\begin{array}{l}\text { Water } \\
\text { Sample }\end{array}$ & $0.494 \pm 0.14^{\mathrm{bb}}$ & BDL & $0.095 \pm 0.05^{\mathrm{b}}$ & BDL & BDL & BDL \\
\hline & $\begin{array}{l}\text { Intestine } \\
\text { Liver }\end{array}$ & $\begin{array}{l}0.548 \pm 0.37^{\mathrm{aa}} \\
0.515 \pm 0.27^{\mathrm{ab}}\end{array}$ & $\begin{array}{c}0.17 \pm 0.047^{\mathrm{b}} \\
\text { BDL }\end{array}$ & $\begin{array}{c}0.698 \pm 0.24^{\mathrm{a}} \\
\mathrm{BDL}\end{array}$ & $\begin{array}{c}15.30 \pm 2.93^{\mathrm{a}} \\
\mathrm{BDL}\end{array}$ & $\begin{array}{c}0.553 \pm 0.28^{\mathrm{a}} \\
\mathrm{BDL}\end{array}$ & $\begin{array}{l}\text { BDL } \\
\text { BDL }\end{array}$ \\
\hline \multirow[t]{2}{*}{$\begin{array}{l}\text { Trimmu } \\
\text { Headworks }\end{array}$} & $\begin{array}{l}\text { Water } \\
\text { Sample }\end{array}$ & $0.517 \pm 0.10^{\text {aa }}$ & BDL & $0.025 \pm 0.01^{\mathrm{b}}$ & BDL & BDL & BDL \\
\hline & $\begin{array}{l}\text { Intestine } \\
\text { Liver }\end{array}$ & $\begin{array}{l}0.420 \pm 0.21^{\mathrm{bb}} \\
0.406 \pm 0.13^{\mathrm{cb}}\end{array}$ & $\begin{array}{c}0.18 \pm 0.107^{\text {a }} \\
\text { BDL }\end{array}$ & $\begin{array}{c}0.66 \pm 0.15^{\mathrm{a}} \\
\mathrm{BDL}\end{array}$ & $\begin{array}{l}\text { BDL } \\
\text { BDL }\end{array}$ & $\begin{array}{l}\text { BDL } \\
\text { BDL }\end{array}$ & $\begin{array}{l}\text { BDL } \\
\text { BDL }\end{array}$ \\
\hline
\end{tabular}

Table 2. Physiochemical parameters of three experimental sites with acceptable ranges.

\begin{tabular}{lcccc}
\hline $\begin{array}{l}\text { Sites/ } \\
\text { Parameters }\end{array}$ & Ravi Campus Ponds & Balloki Headworks & Trimu Headworks & Acceptable Ranges \\
\hline DO (mg/L) & & & & \\
Temp. $\left({ }^{\circ} \mathbf{C}\right)$ & $3.40 \pm 0.216^{\mathrm{a}}$ & $2.36 \pm 0.097^{\mathrm{b}}$ & $2.50 \pm 0.326^{\mathrm{b}}$ & $3-5 \mathrm{mg} / \mathrm{L}$ \\
TDS (mg/L) & $25.73 \pm 0.543^{\mathrm{a}}$ & $23.46 \pm 1.309^{\mathrm{a}}$ & $26.00 \pm 0.816^{\mathrm{a}}$ & $15-35^{\circ} \mathrm{C}$ \\
EC $(\mathbf{m S} / \mathbf{c m})$ & $947.00 \pm 45.760^{\mathrm{a}}$ & $132.66 \pm 17.745^{\mathrm{c}}$ & $251.33 \pm 10.964^{\mathrm{b}}$ & $400 \mathrm{mg} / \mathrm{L}$ \\
pH & $1.23 \pm 0.047^{\mathrm{a}}$ & $0.30 \pm 0.081^{\mathrm{b}}$ & $0.50 \pm 0.163^{\mathrm{b}}$ & $15-50 \mathrm{mS} / \mathrm{cm}$ \\
\hline
\end{tabular}




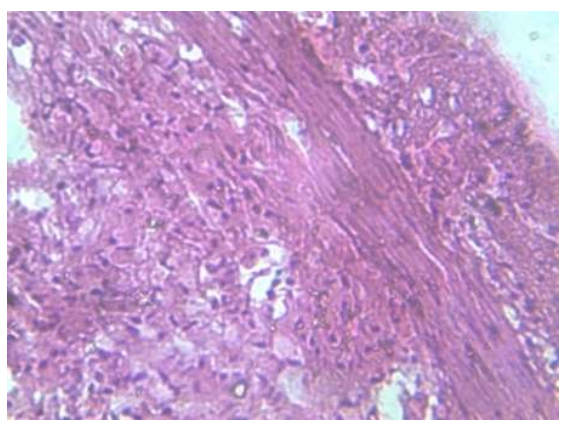

Fig.1

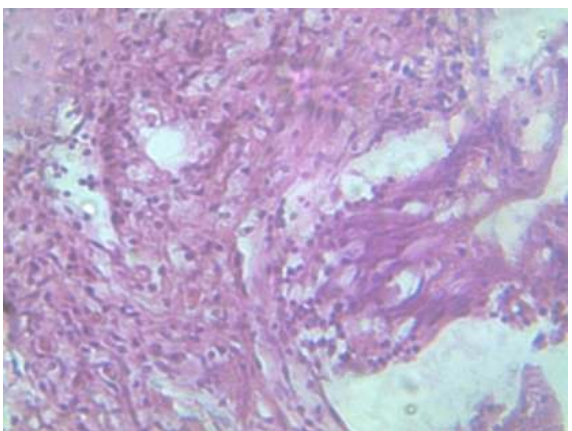

Fig.4

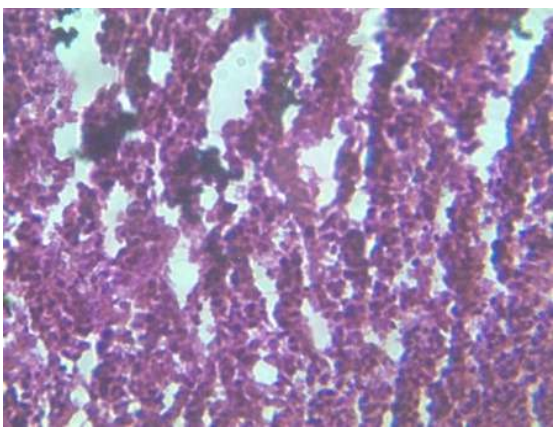

Fig.7

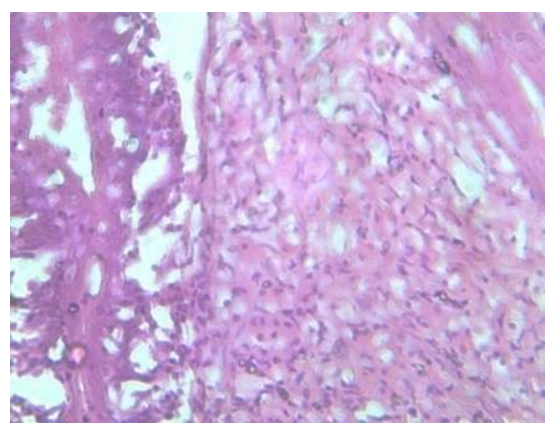

Fig.2

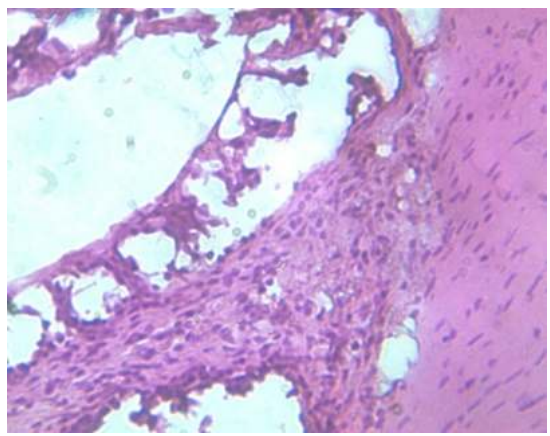

Fig. 5

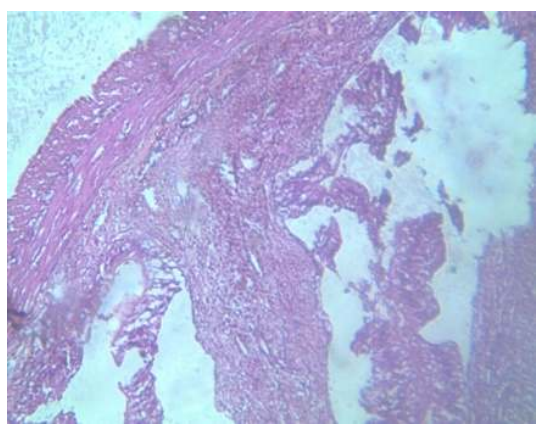

Fig.8

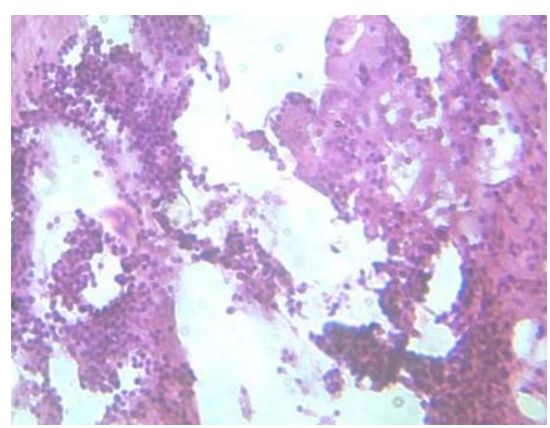

Fig. 3

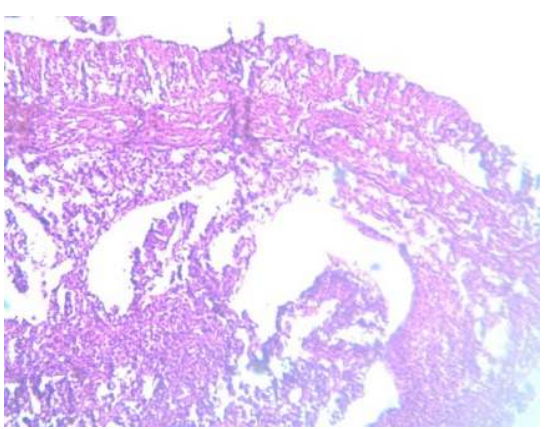

Fig. 6

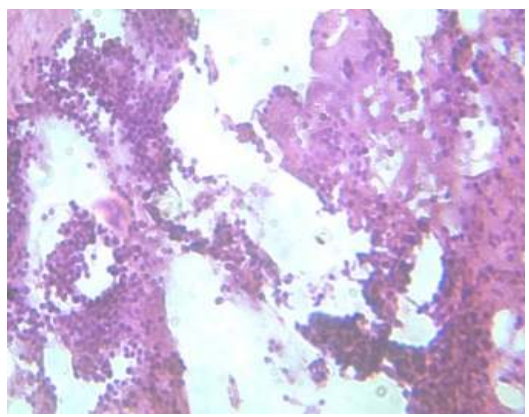

Fig. 9

Fig. 1-9. Fish Intestine: Indicating liffted off and narcotized gut mucosa, rounded and individual epithelial with dense chromatin. Acute inflamtory response of mucosa sloughed into the lumen, hyperaemia and infiltration of macrophages.

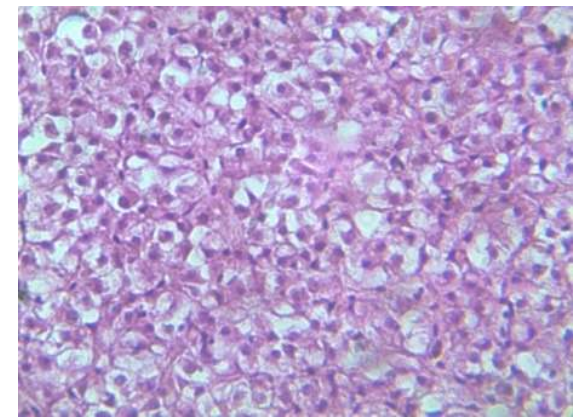

Fig. A

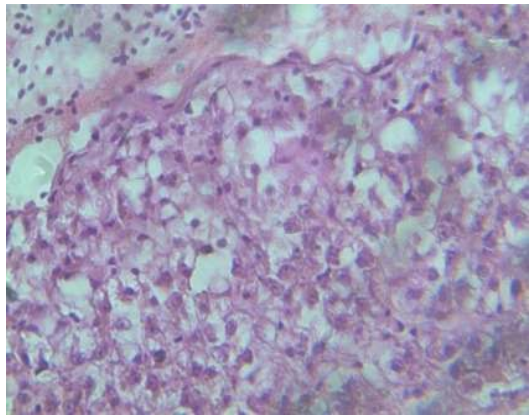

Fig. B

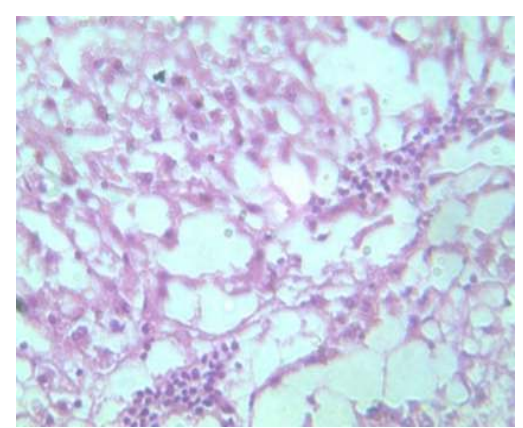

Fig C 


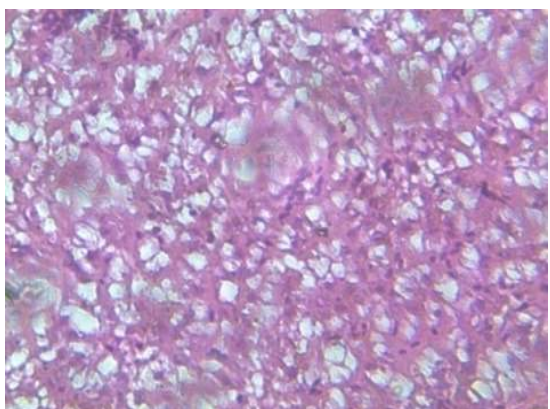

Fig. D

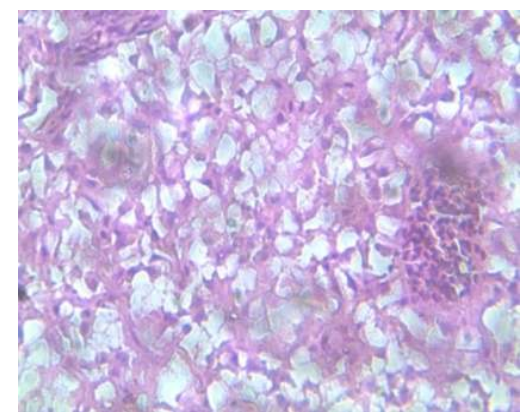

Fig. $\mathbf{E}$

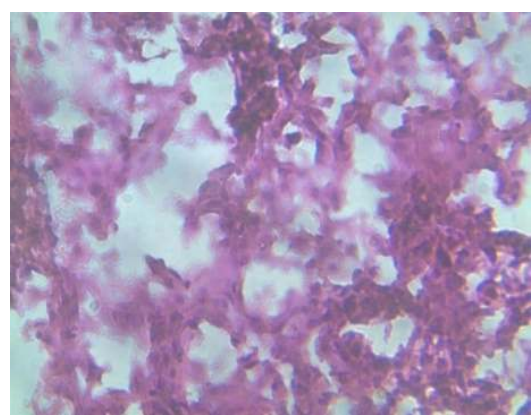

Fig F

Fig. A-F Fish Liver: Indicating the inflamation, confluent necrosis, infractive necrosis, malignant hepatoma, fatty infiltration, intracellular oedema and intracellular nodules in the liver of wild fish samples.

\section{REFERENCES}

Ahmad, Q., L. Bat and F. Yousaf (2015) Accumulation of heavy metals in tissues of long tail tuna from Karachi Fish Harbor, Pakistan. Aquatic Sci. and Tech.3: 103-115.

Alazemi, B.M., J.W. Lewis and E.B. Andrews (1996). Gill damage in the freshwater fish Gnathonemus petersii (Family: Mormyridae) exposed to selected pollutants: An ultra-structural study. Environ. Technol. 17: 225-238.

Al-Ghanim, K.A., 1. M. Abdelatty, L. Abdelfattah and S. Mahboob (2015) Differential Uptake of Heavy Metals by Gill, Muscles and Liver of Four Selected Fish Species from Red Sea. Pakistan J. of Zoo. 47(4): 1031-1036.

Authman, M.M.N., S.A. Ibrahim, M.A. El-Kasheif and H.S. Gaber (2013). Heavy metals pollution and their effects on gills and liver of the Nile catfish (Clarias gariepinus) inhabiting El-Rahawy Drain. Egypt. Global Veter. 10:103-115.

Azaman, F., H. Juahir, K. Yunus, A. Azid, M.K.A.K. Kamarudin, M.E. Toriman, A.D. Mustafa, M.A. Amran, C.N.C. Hasnam and A.S.M. Saudi (2015). Heavy metal in fish: analysis and human health-a review. Jurnal Teknologi. 77 (1): 6169.

Bernet, D.H., W. Schmidt, P. Meier, H. Burhardt and T. Wahli (1999). Histopathology in fish: proposal for a protocol to assess aquatic pollution. J. Fish. Dis. 22: 2534

Braunbeck, T., (1998). Cytological alterations in fish hepatocytes following in vivo and in vitro sublethal exposure to xenobiotics-structural biomarkers of environmental contamination. In: Fish ecotoxicology (eds. T. Braunbeck, D.E. Hinton, B. Streit), Basel. pp. 61-140

Cardwell, R.D., D.K. Deforest, K.V. Brix and W.J. Adams (2013). Do $\mathrm{Cd}, \mathrm{Cu}, \mathrm{Ni}, \mathrm{Pb}$, and $\mathrm{Zn}$ biomagnify in aquatic ecosystems? Rev. Environ. Contam. Toxicol. 226: 101-122.
Chatha, A., M.N. Khan, S. Zahid and M.A. Ali (2016). Heavy metal (cadmium, lead, and chromium) contamination in farmed fish: a potential risk for consumers' health. Turkish J. Zoo. 40: 1-9.

Fatima, M. and N. Usmani (2013). Histopathology and bioaccumulation of heavy metals $(\mathrm{Cr}, \mathrm{Ni}$ and $\mathrm{Pb}$ ) in fish (Channa striatus and Heteropneustes fossilis) tissue: A study for toxicity and ecological impacts. Pakistan J. Biol. Sci. $16: 412-420$.

Fatoki, O.S. and S. Mathabatha (2001) An assessment of heavy metals pollution in the East London and Port Elizabeth Harbors. Water SA. 27:233-236

Gabriel, U.U., E.U. Amakiriand and G.N.O. Ezeri (2007a). Haematology and Gill Pathology of Clarias Gariepinus Exposed to Refined Petroleum Oil, Kerosene under Laboratory Conditions. J. Anim. and Vet. Advances. 6(3):461-465.

Gabriel, U.U.U., G.N.O. Ezeri and E.U. Amakiri (2007b). Liver and kidney histopathology: Biomarkers of No. 1 fuel toxicosis inAfrican cat fish Clarias gariepinus. J. Anim. Veter. Advan. 6:379-384.

Guevara-Riba, A., A. Sahuquillo, R. Rubio and G. Rauret (2004). Assessment of metal mobility in dredged harbour sediments from Barcelona, Spain. Science of the Total Environment. 321: 245-255.

Hadi, A.A. and S.F.Alwan (2012). Histopathological changes in gills, liver and kidney offresh water fish, Tilapia zilli, exposed to aluminum. Int. J. Pharma. Life. Sci. 3: 2071-2081.

Hinton, D.E. and D.J. Lauren (1990). Liver structural alterations accompanying chronic toxicity in fishes: Potential biomarkers of exposure. In: Biomarkers of Environmental Contamination, McCarthy, J.F. and L.R. Shugart (Eds.). Lewis Publishers, Boca Raton, FL., USA., ISBN: 0873712846, pp: 51-65.

Hussain, M., S. Muhammad, N.M. Riffat, M.U. Khan and F. Umar (2014). Status of Heavy Metal Residues in Fish Species of Pakistan. Reviews of 
Environmental Contamination and Toxicology. 230: 111-132.

Izuchukwu, U.I., D.O. Okeke and V.E. Okpashi (2017). Determination of Heavy Metals in Fish Tissues, Water and Sediment from the Onitsha Segment of the River Niger Anambra State Nigeria . J. Environ. Anal. Toxicol. 7: 95.

Jabeen, G. and M. Javed (2013). Evaluation of arsenic toxicity to biota in river Ravi (Pakistan) aquatic ecosystem. Int. J. Agric. Biol. 13: 929-934.

Javed, M. and N. Usmani (2013) Assessment of heavy metal $(\mathrm{Cu}, \mathrm{Ni}, \mathrm{Fe}, \mathrm{Co}, \mathrm{Mn}, \mathrm{Cr}, \mathrm{Zn})$ pollution in effluent dominated rivulet water and their effect on glycogen metabolism and histology of Mastacembelus armatus. Springer Plus. 2:390.

Javed, M. and Saeed, M. A. (2010). Growth and bioaccumulation of Iron in body organs of catla, Labeo rohita and Cirrhina mrigala during chronic exposures. International J. Agriculture and Biology, 12: 881-88

Khan, B., H. Khan, S. Muhammad and T. Khan (2012). Heavy metals concentration trends in three fish species from Shah Alam River, Khyber Pakhtunkhwa Province, Pakistan. J. Nat. Environ. Sci. 1:1-8.

Khan, M.I., M. Khisroon, A. Khan, N. Gulfam, M. Siraj, F. Zaidi, Ahmadullah, Abidullah, S.H. Fatima, S. Noreen, Hamidullah, Z.A. Shah and F. Qadir (2018). Bioaccumulation of Heavy Metals in Water, Sediments, and Tissues and Their Histopathological Effects on Anodonta cygnea (Linea, 1876) in Kabul River, khyber Pakhtunkhwa, Pakistan. BioMed Res. Int.10 pages.

Khan, M.U., R.N. Malik and S. Muhammad (2013) Human health risk from heavy metal via food crops consumption with wastewater irrigation practices in Pakistan. Chemosphere 93(10): 2230-2238.

Latif, A., M. Ali, R. Kaoser, R. Iqbal, K. Umer, M. Latif,,S. Qadir and F. Iqbal (2012) Effect of cadmium chloride and ascorbic acid exposure on the vital organs of freshwater Cyprinid, Labeo rohita. African J. Biotechno. 11(32): 8398-8403.

Mills, W.M. Part I (Revise 1995), EPA 600/6-85/002a. Washington, DC 20460: USA EPA Office of Research and Development.

Mishra, A. and B. Mohanty (2008a). Acute toxicity impacts of hexavalent chromium on behavior and histopathology of gill, kidney and liver of the freshwater fish, Channa punctatus (Bloch). Environ. Toxicol. Pharmacol. 26:136-141.

Mishra, A.K. and B. Mohanty (2008b). Histopathological effects of hexavalent chromium in the ovary of a freshwater fish Channa punctatus (Bloch). Bull. Environ. Contam.Toxicol. 80: 507-511.
Muhammad, S., M.T. Shah and S. Khan (2010). Arsenic health risk assessment in drinking water and source apportionment using multivariate statistical techniques in Kohistan region, northern Pakistan. Food and Chem. Toxicolo. 48(10): 2855-2864.

Muhammad, S., M.T. Shah and S. Khan 2011. Health risk assessment of heavy metals and their source apportionment in drinking water of Kohistan region, northern Pakistan. Microchem. J. 98(2): 334-343.

Parvathi, P.K., S. Mathan and R. Sarasu (2011). Sublethal effects of chromium on some biochemical profiles of the freshwater teleost, Cyprinus carpio. Int. J. App. Biol. Pharma. Techno. 2:295-300.

Qadir, A. and R.N. Malik (2011). Heavy metals in eight edible fish species from two polluted tributaries (Aik and Palkhu) of the River Chenab, Pakistan. Biol. Trace. Elem. Res. 143: 1524-1540.

Qadir, A. R.N. Malik, T. Ahmad and A.M. Sabir (2009). Patterns and distribution of fish assemblage in Nullah Aik and Nullah Palkhu Sialkot, Pakistan. Biolo. Div. and Cons. 2: 110-124.

Rahman, M.S., N. Saha, A.H. Molla and S.M. Al-Reza (2014). Assessment of Anthropogenic Influence on Heavy Metals Contamination in the Aquatic Ecosystem Components: Water, Sediment and Fish. Soil and Sediment Contamination: An Int. J. 23(4): 353-373.

Rajeshkumar, S. and X. Li (2018). Bioaccumulation of heavy metals infish species from the Meiliang Bay, Taihu Lake, China. Tocxocology reports. 5: 288-295.

Rauf, A. M. Javed and M. Ubaidullah (2009). Heavy metal levels in three major carps (Catla catla, Labeo rohita and Cirrhina mrigala) from the river Ravi, Pakistan. Pakistan Vet. J. 29: 24-26.

S.M.E.W.W., 1989. Standard Methods for the Examination of Water and Wastewater (17th Ed.), A.P.H.A., Washington, D.C., USA.

Shah, M.T., J. Ara, S. Muhammad, S. Khan and S. Tariq (2012) Health risk assessment via surface water and sub-surface water consumption in the mafic and ultramafic terrain, Mohmand agency, northern Pakistan. J. Geochem. Explor. 118:60 67.

Shah, M.T., J. Ara, S. Muhammad, S. Khan, S.A. Asad and L. Ali (2013) Potential heavy metal accumulation of indigenous plant species along the mafic and ultramafic terrain in the Mohmand agency, Pakistan. Clean. Soil, Air, Water. 42 (3): 339-346.

Shivakumar, C.K., B. Thippeswamy, M.V. Tejaswikumar and S.M. Prashanthakumara (2014). Bioaccumulation of heavy metals and its effect 
on organs of edible fishes located in Bhadra River, Karnataka. Int. J. Res. Fish. \& Aqua. 4: 90-98.

Steel, R.G.D., J. H. Torrie and D. A. Dickey (1996). Principles and procedures of statistics. $3^{\text {rd }}$ Edition, New York, NY: McGraw Hill Book Company.

Tao, J.S., Liu, R.R. Dawson, C. Cao and B. Li (1999). Uptake of particulate lead via the gills of fish (Carassius auratus). Arch. Environ. Contam. Toxicol., 37: 352-357.

Van Dyk, J.C., G.M. Pieterse and J.H.J. Van Vuren (2007) Histological changes in the liver of Oreochromis mossambicus after exposure to cadmium and zinc. Ecotox. Environ. Saf. 66:432-440.

Verlecar, X.N., N. Pereira, N. Desai, S.R. Jena and K.B. Snigdh, 2006. Marine pollution detection through biomarkers in marine bivalves. Curr. Sci. 91: 1153-1158.

Waseem, A., J. Arshad, F. Iqbal, A. Sajjad, Z. Mehmood and G. Murtaza (2014) Pollution status of Pakistan: a retrospective review on heavy metal contamination of water, soil, and vegetables," BioMed Res. Int. I: 29

WHO (World Health Organisation) (2008). Guidelines for drinking water quality, 3rd edition. Recommendations. World Health Organisation Press, World Health Organisation, Geneva, Switzerland, 1:1- 459.

Younis, E., A.A. Abdelwahab, N.A. Al-Asgah, H. Ebaid and M. Mohamed (2013). Histological Changes in the Liver and Intestine of Nile Tilapia, Oreochromis niloticus, Exposed to Sublethal Concentrations of Cadmium. Pakistan J. Zoo. 45(3):833-841. 